\title{
DETERMINATION EXTENSIONAL VISCOSITY AND CRACKING INDEX OF SULFURE WASTE MODIFIED ASPHALT CEMENT
}

\author{
Abdullah M. RASHED* and Al-Hadidy AI** \\ * Dept. of Road Construction, Duhok technical Institute, Duhok polytechnic university, Kurdistan Region-Iraq \\ ** Dept. Civil Engineering, College of Engineering, University of Mosul-Iraq
}

(Received: October 5, 2020; Accepted for Publication: February 16, 2021)

\begin{abstract}
In the northern Iraqi provinces, cracking distress due to the variations in temperatures is occurred in most of paved roads with asphaltic materials. This type of distress results in alligator and longitudinal cracking, spallings due to temperatures variations. This research determined the index of cracking and extensional viscosity of sulfur waste/asphalt cement (SWMAC). Four dosages of sulfur waste were selected and mixed into 40-50 pent. grade asphalt binder. Physical tests including: penetration, ductility, softening degree, absolute viscosity, elastic moduli, temperature effects, ageing, index of cracking, extensional viscosity, and morphology assays were performed on SWMAC. SWMAC presents higher extensional viscosity, moduli of elasticity and durability traits with superior cracking resistance at low temperature.
\end{abstract}

KEYWORDS:Sulfur waste; Ageing; Index of Cracking; Extensional viscosity.

\section{INTRODUCTION}

In the northern Iraqi provinces, cracking distress due to the variations in temperatures is occurred in most of paved roads with asphaltic materials. This type of distress results in alligator and longitudinal cracking, spallings due to temperatures variations. Thus reduction in life of pavements is happening. Theerefore evaluation of the rheological trais of asphalt seems essential.Warm mix asphalt additives (WMAA) plays significant role in manufacturing desired binder and mixture characteristics [1]. Thus, chosen of WMAA type is importance and depends on bitumen. Different kinds of WMAA are available worldwide, such as natural zeolite (NZ), synthetic zeolite (SZ), sasobit, Evotherm, Terex-foaming, Cecabase, Asphamin [1].

Asphalt mixes containing different kinds and contents of polymers present good application for the design of asphaltic pavements [2-16]. Due to the higher cost of the polymer and solid waste disposal problem, a need for alternative, cheapest modifiers that nonetheless impart enhanced characteristics comparable with the using of expensive polymers.

Nineveh is one Iraqi city having Al-Meshrak state for manufacturing of sulfur. This state company produces between 20 and $25 \%$ sulfur waste (SW) from the total production. SW is a fine gray to green powder mainly composed of sulfur, carbon and ash. It consists of 88 to 90 percent sulfur, 10 to 12 percent carbon, and small amount of ash $(0.1$ percent $)$. The SW specific gravity ranges between 2.03 to 2.215 . In addition, SW represents an ideal modifier for asphalt due to its lower cost. However, the optimum SW dosage for each type of bitumen still needs to be determined. It is supposed that an interaction happens between the bitumen and the SW alters the SW/bitumen binder characteristics, thus enhance the pavement performance.

On the other hand, the rheological characteristics of SW/ asphalt are quite scarce. Some data were documented by [18]. Ahmed et al. [18] were mixed $40 \% \mathrm{SW}$ into 60-70 penetration grade asphalt binder. It was found that the ductility value of virgin asphalt decrease by $44 \%$, whereas, the penetration value was increased by $9.3 \%$.

However, this study tries to calculate the (1) penetration at $25^{\circ} \mathrm{C}(\mathrm{P} 25)$, ductility at $25 \mathrm{deg}$. C (D25), softening degree (Ring\&Ball point), absolute viscosity at $21 \mathrm{deg}$. C (A.V), elastic moduli (Eb.), penetration index (PI.), oxidation (ageing), cracking index (CI.), and extensional viscosity traits of SW/asphalt cement (SWMAC), then the tests results are compared with the virgin asphalt, and (2) the extensional viscosity of SW/asphalt mix (SWMAM), and compared the tests results with virgin mixes. 


\section{RESEARCH OUTLIES}

Traditional traits (penetration at $25 \mathrm{deg}$. C, ductility at $25 \mathrm{deg}$. $\mathrm{C}$, softening degree, viscosity at $21 \mathrm{deg}$. C, elastic moduli, \% losses in weight due to effects of heat and air at 163 deg.C (ageing), ageing index, cracking index, temperature effects, morphology, extensional viscosity of SWMAC, and SWMAM were performed in the current research.

\section{UTILISED MATERIALS AND TESTING PROCEDURES}

\subsection{Asphalt cement}

Asphalt cement of 40-50 pentreation grade was utilised to produce SWMAC. Table 1 summarizes the tradintional asphalt properties.

Table (1): Physicochemical properties of asphalt cement

\begin{tabular}{|c|c|c|c|c|c|c|c|}
\hline 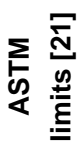 & $\begin{array}{l}0 \\
\text { L } \\
\text { ơ }\end{array}$ & $\begin{array}{l}\infty \\
\text { م⿱⺈ } \\
\text { o } \\
\text { ம }\end{array}$ & $\frac{8}{1}$ & 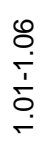 & $\underset{\wedge}{\stackrel{ }{N}}$ & 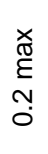 & \\
\hline 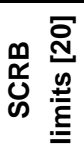 & $\begin{array}{l}\text { o } \\
\text { ò } \\
\text { ம }\end{array}$ & 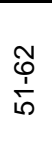 & $\frac{8}{1}$ & ' & ' & ' & \\
\hline 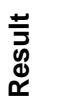 & ฯ & \& & 莡 & $\begin{array}{l}\stackrel{\mathscr{D}}{0} \\
\stackrel{-}{-}\end{array}$ & $\underset{N}{\mathbb{N}}$ & 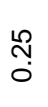 & 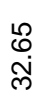 \\
\hline 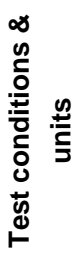 & $\begin{array}{l}0 \\
\tilde{D} \\
\delta \\
8 \\
0 \\
0 \\
\dot{0} \\
\dot{0} \\
0 \\
\stackrel{0}{0}\end{array}$ & 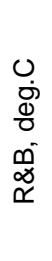 & $\begin{array}{l}0 \\
0 \\
0 \\
\dot{8} \\
\dot{0} \\
\stackrel{0}{0}\end{array}$ & 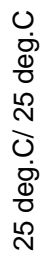 & $\begin{array}{l}0 \\
\dot{8} \\
0 \\
0 \\
0 \\
0\end{array}$ & $\begin{array}{l}\circ \\
0 \\
0 \\
\dot{\Phi} \\
0 \\
0 \\
\mathbb{0} \\
\underline{0} \\
\ddot{\bar{E}}\end{array}$ & $\circ^{\circ}$ \\
\hline 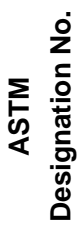 & $\stackrel{\circ}{\circ}$ & Oొ & $\frac{m}{\frac{m}{\sigma}}$ & 옴 & ๙ั & $\frac{\stackrel{+}{\circ}}{\frac{5}{0}}$ & $\begin{array}{l}\text { ○ } \\
\text { ઠิ }\end{array}$ \\
\hline 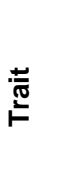 & 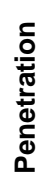 & 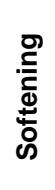 & 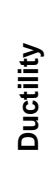 & $\begin{array}{l}\text { के } \\
\text { के }\end{array}$ & 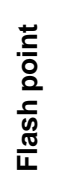 & 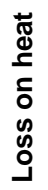 & 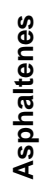 \\
\hline
\end{tabular}

\subsection{SW modifier}

The SW in powder form with four different dosages was blended into Iraqi asphalt cement (40-50 pen.). SW was blended with 40-50 pen. for 8-12 minutes at $150^{\circ} \mathrm{C}$ using a mixer of 500 rpm [19]. Table 2 presents the SW traits.

Table (2): Physicochemical properties of sulfur waste

\begin{tabular}{cc}
\hline Element & Weight, \% \\
\hline Total sulfur & 92.3 \\
\hline Combined sulfur with carbon & 13.2 \\
\hline Free sulfur & 79.02 \\
\hline Total carbon & 7.63 \\
\hline Bitumen & 0029 \\
\hline Ash as a pentonite & 0.0693 \\
\hline Carbonized materials & 20.985 \\
\hline Sp.gr. & 2.03
\end{tabular}

\section{DISCUSSIONS OF TESTING RESULTS}

\subsection{Physical properties}

Table 3 presented the physical properties for SWMAC. The tests results show that SW has a significant effect on the physical properties as shown from the P25C, D25C and R\&B values. $10 \%$ SWMAC present $83 \%$ higher P25C, $13 \%$ lower R\&B than virgin asphalt. This reveals that SW varies virgin asphalt performance. This is due to the recrystalization of sulfur [19].

As can be seen in Table 3, 10\%SWMAC satisfied the lowest limits of $\geq 100 \mathrm{~cm}$ set by SCRB [20] and ASTM [21] specifications.

Table (3): Physicochemical properties of SWMAC

\begin{tabular}{ccccc}
\hline \% SW & P25C & D25C & $\begin{array}{c}\mathbf{T}_{\text {R\&B }} \\
\text { deg.C }\end{array}$ & $\begin{array}{c}\text { A.V, 21deg.C } \\
\text { (poises) }\end{array}$ \\
\hline 0.0 & 42.0 & $\geq 150$ & 54.0 & $5.0 \times 10^{6}$ \\
\hline 10 & 77 & 112 & 47 & $1.33 \times 10^{6}$ \\
\hline 20 & 74.5 & 76 & 45.2 & $1.43 \times 10^{6}$ \\
\hline 30 & 68 & 31.7 & 43.4 & $1.74 \times 10^{6}$ \\
\hline
\end{tabular}

The viscosity at $21 \mathrm{deg}$. C in poises (A.V) of SWMAC was calculated utilizing shell graph. Table 3 presents the A.V and SW dosages. The results indicate that $10 \%$ SWMAC show $73.4 \%$ lower AV than 40-50 pen.

\subsection{Elastic moduli}

The elastic moduli (asphalt stiffness) of SWMAC were calculated utilizing Eq. No. 1 as depicted in the graph of Van der poel and as reported by [22], [23].

$E_{b}=\left(\frac{1.157}{10^{7}}\right) * \tau^{\frac{1}{0.368}} * 2.718^{\frac{1}{P I}}(R \& B-$ $\left.T_{\text {asph }}\right)^{5}$

Where:

$E_{b}=$ Elastic moduli of binder (N/sq.mm)

$T_{R \& B}=$ Softening degree of the recovered binder (deg.C), 
$\mathrm{T}_{\text {asph }}=$ Temperature of the asphalt layer (deg.C),

$\mathrm{PI} .=\mathrm{PI}$. of the recovered binder, and

$\tau=$ Loading time $(0.02$ secs $)$.

Equation 1 can be adopted when:

$1 / 100 \mathrm{sec}<\tau<1 / 10 \mathrm{sec}$,

$-1<$ P.I. $<+1$,

20deg. $\mathrm{C}<\left(\right.$ R\&B $\left.-\mathrm{T}_{\text {asph }}\right)<60$ deg.C.

$\mathrm{T}_{\text {aspha. }}=25^{\circ} \mathrm{C}$

Figure 1 presents that $10 \%$ SWMAC have $29.4 \%$ higher Eb. than 40-50 pen.

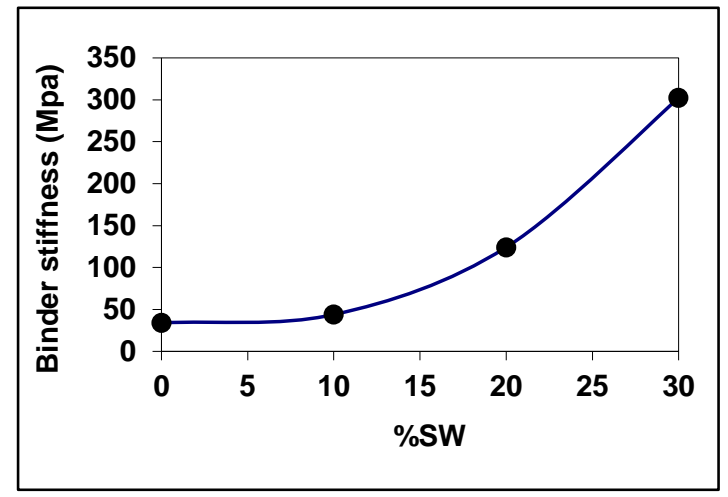

Fig. (1): Binder stiffness of SWMAB

\subsection{Temperature Susceptibility}

Temperature effect of SWMAC was obtained by P.I [Equation 2] [24]:

$$
\begin{aligned}
& P . I=\frac{(0.2-5 Z)}{(0.01+0.5 Z)} \ldots \ldots \ldots \ldots \ldots \ldots \ldots \\
& Z=\frac{(\log \text { pent. @ } \mathrm{T}-\log 800}{T-R \& B}
\end{aligned}
$$

Where:

$\mathrm{T}=$ Testing temperature

$\mathrm{R} \& \mathrm{~B}=$ Softening degree

PI. test results, as depicted in Figure 2, reveals that the preliminary and extruded P.I values for $10 \%$ SWMAC lies between -1 and -0.5 as depicted in KSLA graph [23], which indicated the SWMA had normal temperature susceptibility.

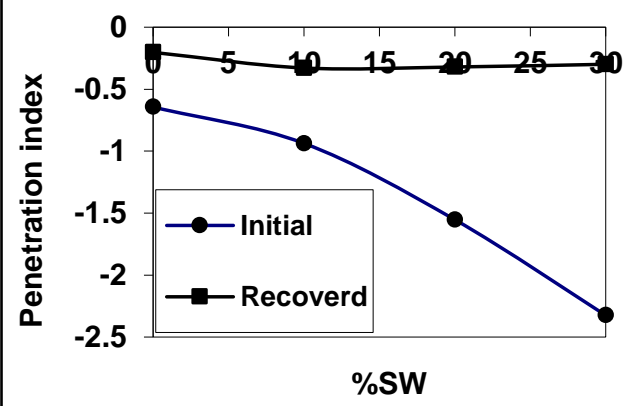

Fig. (2): Penetration index of SWMAB

\subsection{Aging (Durability) Characteristics}

P25, D25 and TR\&B after thin film oven test $($ TFOT $)$ were determined. Aging index $(\mathrm{AI})=$ (residue P25/ P25) was also determined as hardening indicator. Table 4 shows the test results, including AI, aged softening point and aged ductility values measured on polymermodified asphalt specimens. SWMAC presented lower AI than 40-50 pen. due to the recrystalization of SW, resulting in the brittleness of the resultant binders [19]. Examining Table 4 indicates that $\mathrm{R} \& \mathrm{~B}$ of aged $10 \%$ SWMAC was increased by $10 \%$, wheares, aged D25 was found to be greater than $100 \mathrm{~cm}$ (the min. value set by SCRB) [20].

Table (4): TFOT Characteristics of SW-asphalt

\begin{tabular}{|c|c|c|c|c|}
\hline 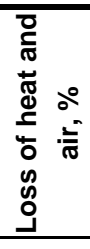 & $\begin{array}{l}\stackrel{L}{0} \\
\stackrel{0}{0}\end{array}$ & 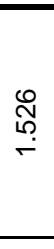 & $\hat{N}$ & $\begin{array}{l}\underset{\sim}{\sim} \\
\dot{\sim}\end{array}$ \\
\hline 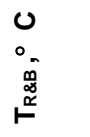 & $\stackrel{6}{\circ}$ & $\frac{n}{6}$ & ㅇ & $\stackrel{R}{1}$ \\
\hline 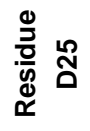 & $\underset{\underset{\sim}{\sim}}{\mathfrak{Y}}$ & 음 & $\mp$ & $\stackrel{n}{\sim}$ \\
\hline$\dot{\dot{\alpha}}$ & $\begin{array}{l}\infty \\
\infty \\
0\end{array}$ & $\begin{array}{l}\hat{8} \\
\text { Oे }\end{array}$ & $\begin{array}{l}8 \\
\circ\end{array}$ & $\begin{array}{l}\text { J্ } \\
\text { : }\end{array}$ \\
\hline 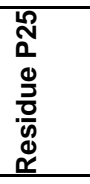 & 网 & $\stackrel{L}{\sim}$ & $\stackrel{L}{\dot{\sim}}$ & $\stackrel{\circ}{\dot{m}}$ \\
\hline $\begin{array}{l}3 \\
\text { o } \\
\text { ১0 }\end{array}$ & 0 & $\stackrel{ }{\circ}$ & 尺 & 이 \\
\hline
\end{tabular}
binders

Table 4 indicates that the percentage loss of SWMAC raises as the sulfue waste dosage raises (i.e. oxidation increased with the sulfur waste addition in SWMAC). This is related to the higher loss by dehydrogenation and oxidation of 40-50 pen. when the SW/asphalt mix exposed to temperature higher than $150^{\circ} \mathrm{C}$, as a result fumes of $\mathrm{H} 2 \mathrm{~S}, \mathrm{So} 2$ and $\mathrm{Co} 2$ can be occurred. 


\subsection{Cracking characteristic at low temperatures}

Cracking of $\mathrm{AC}$ - pavements is due to the presence of low temperature, which produces materials tensile stress and in turn results in fracture [25]. A lot of evaluating procedures for transverse cracking distresses have been utilised in the literature. Cracking index $(\mathrm{CI})$ is one of the most widely used approaches in determining the pavement cracking. Al-ani [26] introduce a good correlation $\left(\mathrm{R}^{2}=0.843\right)$ for predicting low temperature cracking based on binders characteristics before and after TFOT. The CI is defined in Eq. (3):

$C I=10.13 * A I^{0.5}+0.334 * \log P$ en.$+\frac{22}{7} *$

$(R \& B)-166.204$

Where

$\mathrm{CI}=$ Cracking Index,

$\mathrm{AI}=$ Index of ageing,

Pen. $=$ Std. penetration $(25$ deg.C),

$\mathrm{R} \& \mathrm{~B}=$ softening degree (deg.C) after ageing.

Results of CI., as presented in Figure 3, reveal that the CI. for $40-50$ pen. and $10 \%$ SW/40-50 pen. are 20.04 and 41.42, respectively. $10 \%$ SW raises the CI. by $106.7 \%$. This depicts that the SWMAC enhances asphalt mixtures resistance against cracking due to their lower temperature susceptibility.

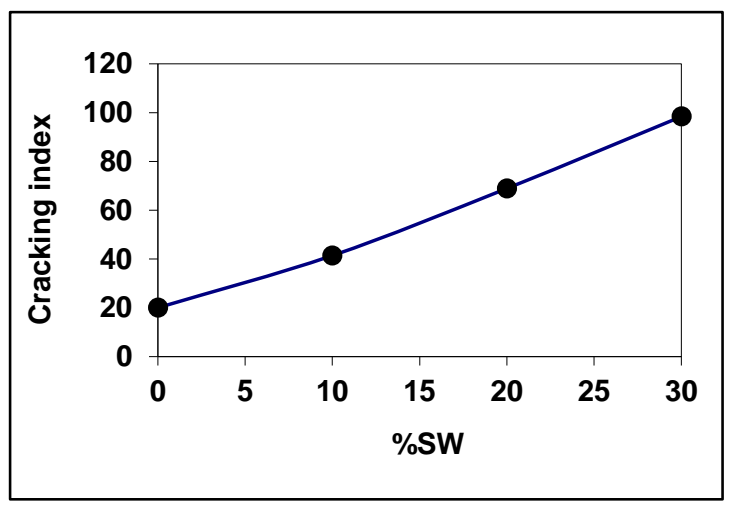

Fig. (3): Cracking index of SWMAC

\subsection{Extensional viscosity}

The extensional viscosity (EV) of SW/virgin asphalt and SW/mix are defined in Equation 4 and Equation 5 [27].

$\lambda_{b}=3 * 10^{-6}\left[1.3 * 10^{\left.\frac{[3+(T R \& B-T a s p h .]}{10}\right]}\right.$

Where:

$\lambda_{b}=E V$ of binder (Mpa.s.),

$\mathrm{T}_{\mathrm{R \& B}}=$ softening degree of extruded asphalt (deg.C), and

$\mathrm{T}_{\text {asph }}=$ Surface temperature ( 25 deg.C).

$$
\begin{gathered}
\log \lambda_{a}=\emptyset_{1}(N)+\emptyset_{2}(N) \log \lambda_{b} \cdots \ldots \ldots \ldots \ldots \ldots \ldots . .(5) \\
\emptyset_{1}(N)=186 * 10^{-5} * N^{2}-165 * 10^{-3} * N \\
+698 * 10^{-2} \\
\emptyset_{2}(N)=75 * 10^{-2}-22 * 10^{-5} * N
\end{gathered}
$$

Where:

$\lambda_{\mathrm{a}}=\mathrm{EV}$ of asphalt mixture (Mpa.s.), and

$\mathrm{N}=$ Mineral aggregate voids (\%).

Figure 4 and Figure 5 present that $10 \% \mathrm{SW}$ raises the $\mathrm{EV}$ of $40-50$ pen. and virgin mix at 60 deg.C by $27 \%$ and $0.0 \%$, respectively. Besides, rising in temperature leads to drop in asphalt binder and mix EV for all SW dosages as presented in Figure 6 and Figure 7.

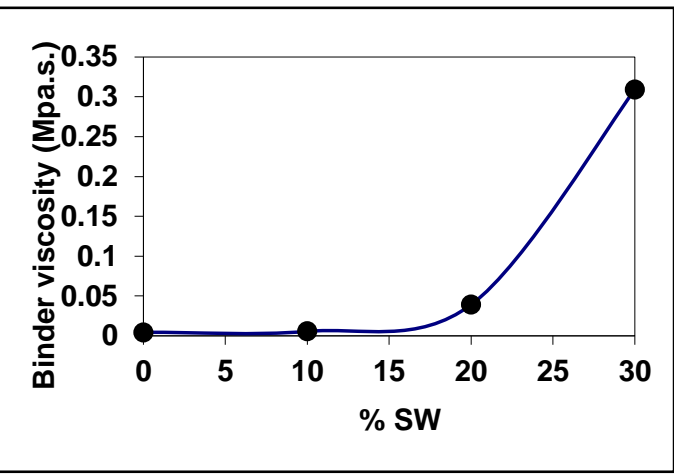

Fig. (4): SWMAC extensional viscosities (60 deg.C)

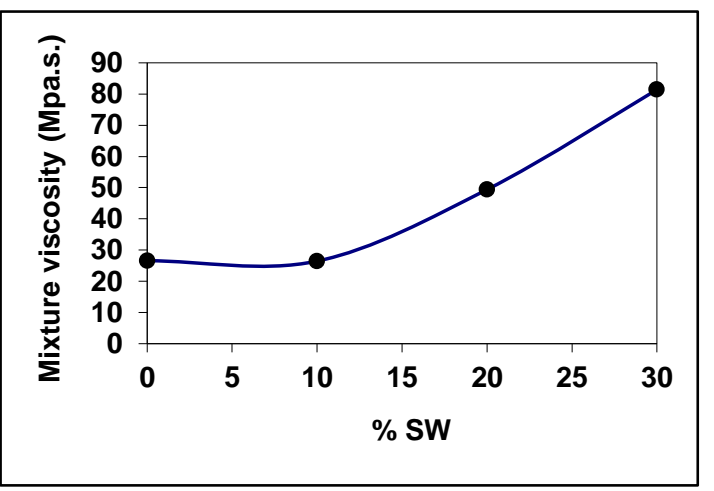

Fig. (5): SWMAC extensional viscosities (60 deg.C)

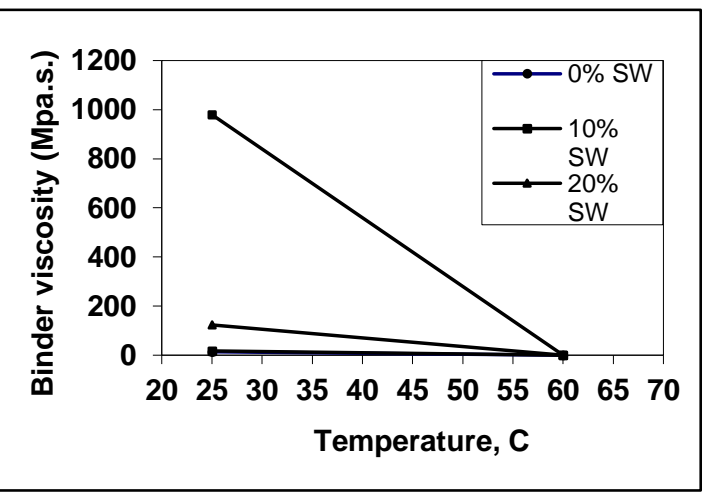

Fig. (6): SWMAC extensional viscosities (25\&60 deg.C) 


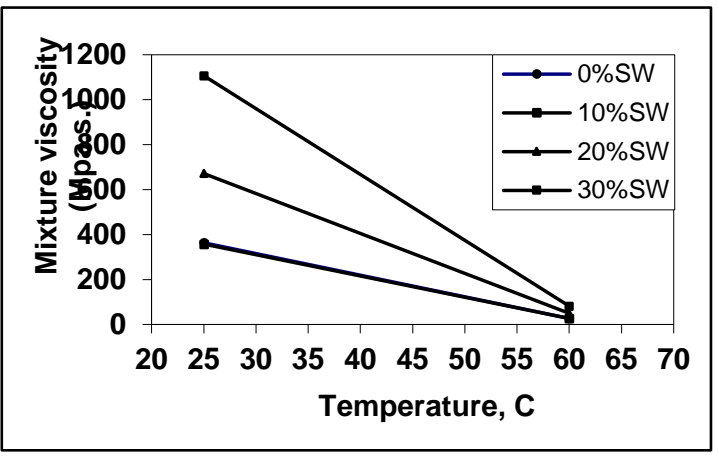

Fig. (7): SWMAC extensional viscosities $(25 \& 60$ deg.C)

\section{CONCLUSION}

From the assays adopted in this research, the following conclusions were presented:

1. Ductility at 25 deg.C reduced as increasing the sulfur waste content increases. This depicts an enhanced in shear resistance of SWMAC in moderate to cold climate.

2. 10\%SWMAC presents ductility value of more than $100 \mathrm{~cm}$ which is the lowest limt set according to SCRB and ASTM specifications.

3. 10\%SWMAC shows $13 \%$ lower R\&B than that for virgin asphalt. This presents that SW decreases the resistance of asphalt mixture against shear deformation.

4. It is noticed that all SWMA binders are more affects by temperature varies compared by virgin. In addition, the $10 \%$ SW content kept on the P.I. value of virgin asphalt at preferable range between -1 and -0.5 as depicted in KSLA graph.

5. The results showed $10 \%$ SW decreases the AV of virgin asphalt about $73.4 \%$.

6. It was found that the addition of $10 \% \mathrm{SW}$ increases the elastic modulus of virgin asphalt about $29.4 \%$.

7. SWMAC presented lowest aging index, which indicates that SWMA binders are more susceptible to aging effects than virgin asphalt.

8. $10 \%$ SW raises the CI. about $107 \%$. This depicts that the SWMAC enhances the asphalt mixtures to resist cracking; and

9. At 60 deg.C, $10 \%$ SWMAC presented $27 \%$ higher extensional viscosities than 40-50 pen.

\section{REFERENCES}

Salim Abdullah Khalid and Al-Hadidy AI (2020). Comparative Rheological and Mechanical Characteristics of Different Warm-Mix Asphalt Additives Under Aging Conditions". Al-Rafidain Engineering Journal (AREJ)Mosul/ Iraq, June, 2020, Vol.25, No.1, Pp.4250.

Wardlaw KR, Shuler S. Polymer-modified asphalt binders. ASTM STP 1108, 1992, Philadelphia, USA

Ostermeyer, Larry F., US.Pat.5221703; 1993.

Lewandowski LH. Polymer modification of paving asphalt binders. Rubber Chemistry and Technology 1994; 67(3): 447-80.

Maccarrone S, Holleran G, Gnanaseelan GP. Properties of polymer-modified binders and relationship to mix and pavement performance. Asphalt Paving Technology 1995; (64): 209-236.

Hesp SAM, Terlouw T, Vonk WC. Low temperature performance of SBS-modified asphalt mixes. Asphalt Paving Technology 2000; (69): 540568.

Jin $\mathrm{H}$, et al. Improved properties of polystyrenemodified asphalt through dynamic vulcanization. Polymer Testing 2002; (21): 633-640.

Uddin W. Viscoelastic characterization of polymermodified asphalt binders of pavement applications. Applied Rheology 2003; 13(4): 191- 199.

Chiu CT, Lu LC. A laboratory study on stone matrix asphalt using ground tire rubber. Construction and Building Materials 2007; (21): $1027-$ 1033.

Wekumbura C, Stastna J, Zanzotto L. Destruction and recovery of internal structure in polymermodified asphalts. ASCE Journal of Materials in Civil Engineering 2007; 19(3): 227-223.

Punith VS, Veeraragavan A. Behavior of Asphalt Concrete Mixtures with Reclaimed Polyethylene as Additive. ASCE Journal of Materials in Civil Engineering 2007; 19(6): 500-507.

Al-Hadidy AI, Tan Y. Long-Term Aging of Polypropylene Asphalt Paving Mixtures. 
Proceedings of the 26th Southern African Transport Conference (SATC 2007), 9 - 12 July 2007. P761-767. ISBN Number: 1-92001702-X Pretoria, accepted as a World Cup 2010 Traffic Simulation.

Al-Hadidy AI, Tan Y. Comparative Performance of the SMAC Made with the SBS and STModified Binders. ASCE Journal of Materials in Civil Engineering 2011; 22(6): 580-587.

Tapkın S, et al. Repeated Creep Behavior of Polypropylene Fiber-Reinforced Bituminous Mixtures. ASCE Journal Of Transportation Engineering 2009; 135(4): 240-249.

Zhao D, Lei M, Yao Z.. Evaluation of PolymerModified Hot- Mix Asphalt: Laboratory Characterization. ASCE Journal of Materials in Civil Engineering 2009; 21(4): 163-170.

Vural Kok B, Yilmaz M. The effects of using lime and styrene-butadiene-styrene on moisture sensitivity resistance of hot mix asphalt. Construction and Building Materials 2009; 23(5): 1999-2006.

.Gorkem C, Sengoz B. Predicting stripping and moisture induced damage of asphalt concrete prepared with polymer modified bitumen and hydrated lime. Construction and Building Materials 2009; 23(6): 2227-2236.

Ahmed et al. (1985) "Using sulfur waste as replacement of asphalt cement in paving constructions". NCCL, No. 28.

Al-Taaei A.K. (1986). "Effect of sulfur on the properties of asphaltic concrete mixtures".
M.Sc. thesis. College of engineering, university of Mosul, Mosul-Iraq.

State cooperation of road and bridges (SCRB). Hot mix asphaltic concrete pavement. Iraqi standard specification, Ministry of Housing and Construction. Department of Design and Study, 1999, Section R-9.

ASTM Standard Specifications, Section 4, 04-03. 2002, Philadelphia, USA.

Anon, (1992) "Residential course on bituminous pavements: materials, design and evaluation." University of Nottingham, Department of Civil Engineering.

Brown SF, Brunton JM. An introduction to the analytical design of bituminous pavements (3rd edition). 1992; University of Nottingham, Department of Civil Engineering, UK.

Huang YH. Pavement analysis and design, 1993; Prentice-Hall, Upper Saddle River, NJ 07458.

Haas, RCG. Thermal shrinkage cracking of some Ontario pavements. Ontario highway department report R.R.161, 1969.

Al-Ani TMA. Influence of accelerated weathering of asphalt cement properties on performance of paving materials. M.Sc. Thesis, university of Baghdad, September, 1999.

Collop AC, Cebon D, Hardy MSA. A visco-elastic approach to rutting in flexible pavements. ASCE Journal of Transportation Engineering 1995; $121(1)$ : $\quad 82 \quad-\quad 93$. 